\title{
Download
}

UDC: 338.486 .2 https://doi.org/10.17721/2308-135X.2021.64.29-41

Lushchyk Mariya Vasylivna, Candidate of Geographical Sciences Lviv Polytechnic National University, Lviv, Ukraine, e-mail: murmarja@gmail.com, https // orcid.org / 0000-0001-5411-348X

Pronko Halyna Volodymyrivna, Lviv Polytechnic National University, Lviv, Ukraine

\section{GEOGRAPHY OF DARK TOURISM IN UKRAINE}

The purpose of the article is to study the resource base for the development of «dark» tourism in Ukraine. Since the issue of «dark» tourism is insufficiently studied in scientific sources, but is already of interest in science and society, scientific attempts to study «dark» tourism in Ukraine are considered relevant and timely.

Methods. The author's analysis of materials of modern scientific researches and researches concerning theoretical and practical aspects of development of «dark» tourism in Ukraine and the world is carried out. A thorough analysis of publications of the current Ukrainian press, popular publications, news media resources, materials of information portals, websites of travel companies has been performed.

Results. The preconditions for the development of «dark» tourism in Ukraine are described. The resource base of this type of tourism is investigated. A list of 120 potentially popular for tourists «dark» places and objects (medieval castles, dungeons, thematic museums, prisons, cathedrals, ancient settlements, cemeteries, anomalous areas, places of power, battlefields and battles, etc.) that can used in the development of new tourism products. According to the monitoring data, a map of «dark» tourism facilities in Ukraine has been completed. The 
geographical (by macro-regions and regions of Ukraine) and thematic (according to the objects belonging to specific types of «dark» tourism: mystical tourism, necropolis tourism, thanatourism and catastrophe tourism) structuring of these objects, and regularities in their geospatial organization are revealed. The most interesting objects of «dark» tourism of the regions of Ukraine are singled out and a brief description of more than 60 destinations is given.

The practical significance. The results of monitoring of «dark» tourism in Ukraine can be used as a database for the development of an interactive map, and their characteristics, presented in the article, become a meaningful content of such a map, as well as used as content to fill thematic websites, information portal, YouTube and Telegram channels, mobile applications. The materials of the article can also be used in the process of forming tourism development programs of the country, in arranging the infrastructure of the relevant profile (quest rooms, amusement parks, thematic entertainment centers), in organizing cultural events, competitions, quests, festivals, educational tours in mystical places to promote them. among tourists and attracting additional investment in the activities of tourism enterprises that plan to expand the existing range of tourism programs by developing «dark» tours and excursions.

Key words: dark tourism, mystical tourism, catastrophe tourism, thanatourism, necropolis tourism.

References

1. Alistratova, K. E. (2013). Misty'chny'j tury'zm: zarubizhny'j dosvid ta perspekty'vy' rozvy'tku v Ukrayini [Mystical tourism: foreign experience and prospects for development in Ukraine]. Geografiya ta tury'zm - Geography and Tourism, 26, 93-101. [in Ukrainian].

2. Arajs, O. S., \& Sologub, Yu. I. (2014). Temny'j tury'zm [Dark tourism]. Naukovi zdobutky' molodi - vy'rishennyu problem xarchuvannya lyudstva u XXI stolitti : programa i materialy' 80 mizhnarodnoyi naukovoyi konferenciyi molody'x ucheny'x, aspirantiv i studentiv - Scientific achievements of youth - solving the problems of human nutrition in the XXI century: program and materials of the 80th international scientific conference of young scientists, graduate students and students. (pp. 482-483). K.: NUXT. Retrieved from http://dspace.nuft.edu.ua/bitstream/123456789/18856/1/286.pdf. [in Ukrainian]. 
3. Bordun, O. Yu., \& Derkach, U. V. (2014). Teorety'chni ta prakty'chni zasady' doslidzhennya poxmurogo tury'zmu Ukrayiny' [Theoretical and practical principles of the study of gloomy tourism in Ukraine]. Geografiya ta tury'zm - Geography and Tourism, 30, 62-72. [in Ukrainian].

4. Bugrij, O. V. (2010). Nekropol'ny'j tury'zm ta jogo ob'yekty' na Ukrayini [Necropolis tourism and its objects in Ukraine]. Geografiya ta tury'zm - Geography and Tourism, 4, 52-62. [in Ukrainian].

5. Decyat' misty'chny'x czvy'ntariv Ukrayiny' [Ten mystical cemeteries of Ukraine]. Retrieved from https://ua.igotoworld.com/ua/article/568_decjat-mistichnih-cvintariv.htm. [in Ukrainian].

6. Desyat' ukrayins'ky'x zamkiv z pry'vy'damy' [Ten Ukrainian haunted castles]. Retrieved from https://busfor.ua/uk/blog/ukrainian-haunted-castles. [in Ukrainian].

7. Dmy'truk, V. I., Dyachenko, L. A., Gry'n'ox, N. V., \& Knyazevy'ch, A. O. (2020). «Bezpechny'j Chornoby'l'» yak novy'j napryam rozvy'tku na mizhnarodnomu ry'nku tury'sty'chny'x poslug [«Safe Chernobyl» as a new direction of development in the international market of tourist services]. Efekty'vna ekonomika - Effective economy, 1. [in Ukrainian].

8. Ezotery'chna karta Ukrayiny' [Esoteric map of Ukraine]. Retrieved from https://www.google.com/maps/d/u/0/viewer?mid=1jW8iEAdWSRgBuJjbC7PBQacbKeU\&Il=49.4 3660555614488\%2C27.060275367525037\&z=. [in Ukrainian].

9. Zastavecz'ky'j, T. B., \& Zastavecz'ka, L. B. (2011). «Poxmury'j tury'zm» yak vidobrazhennya tragichny'x podij u istoriyi ta kul'turi narodiv ["Gloomy tourism» as a reflection of tragic events in the history and culture of nations]. Rekreacijna geografiya i tury'zm. Naukovi zapy'sky' Recreational geography and tourism. Scientific notes, 1, 101-107. [in Ukrainian].

10. Ivanov, A. M. (2011). «Temny'j» tury'zm yak ody'n z perspekty'vny'x vy'div tury'zmu [«Dark» tourism as one of the promising types of tourism]. Biznes-navigator - Business Navigator, 5 , 186-191. Retrieved from http://www.library.univ.kiev.ua/ukr/host/viking/db/ttp/univ/gat/gat_2013_24.pdf\#page=67. [in 
Ukrainian].

11. Ivchenko, L. O., \& Romanova, K. M. (2020). Dy'namika i perspekty'vy' rozvy'tku tury'zmu v Chornoby'l's'kij zoni [Dynamics and prospects of tourism development in the Chornobyl zone]. Elektronne naukove faxove vy'dannya Efekty'vna ekonomika - Electronic scientific professional publication Effective Economy, 1. [in Ukrainian].

12. Informacijne vy'dannya «Misty'chni zamky' Zaxidnoyi Ukrayiny'» [Information publication «Mystical Castles of Western Ukraine»]. Materialy' zibrani ta vporyadkovani: Vy'stavkovy'j centr LIET «Tury' ta tury'sty'chni produkty' dlya I'viv'yan ta gostej mista». Tury'sty'chno-informacijny'j centr LIET - Materials collected and arranged: Exhibition Center LIET "Tours and tourist products for Lviv residents and guests of the city." // Tourist Information Center LIET. [in Ukrainian].

13. Kaz'my'rchuk, M. (2016). Memorial'ny'j i nostal'gijny'j tury'zm u vitchy'znyany'x i zarubizhny'x doslidzhennyax [Memorial and nostalgic tourism in domestic and foreign research]. Visny'k Ky'yivs'kogo nacional'nogo universy'tetu im. T. Shevchenka. Istoriya - Bulletin of Kyiv National University. T. Shevchenko. History, 4, 20-31. [in Ukrainian].

14. Ky'ry'lyuk, L. M. (2008). Novi (netrady'cijni) vy'dy' tury'zmu Ukrayiny' [New (non-traditional) types of tourism in Ukraine]. Naukovi zapy'sky' VDPU im. M. Kocyuby'ns'kogo. Seriya: geografiya. - Scientific notes of VSPU. M. Kotsyubynsky. Series: geography., 17, 191-195. [in Ukrainian].

15. Klyap, M. P., \& Shandor, F. F. (2011). Suchasni riznovy'dy' tury'zmu: navchal'ny'j posibny'k [Modern varieties of tourism: a textbook]. K.: Znannya. [in Ukrainian].

16. Kuly'nyak, I. Ya., Yarmola, K. M., \& Malishevs'ka, B. O. (2020). Perspekty'vy' rozvy'tku misty'chnogo tury'zmu v Ukrayini [Perspectives of development of mystical tourism in Ukraine]. Materialy' Mizhnarodnoyi naukovoyi konferenciyi. «Formuvannya suchasnoyi naukovoyi dumky'» - Materials of the International scientific conference. «Formation of modern scientific thought» (pp. 53-56). Kropy'vny'cz'ky'j: MCzND. [in Ukrainian]. 
17. Kuly'nyak, I Ya., Zhy'galo, I. I., \& Yarmola, K. M. (2020). Misty'chny'j tury'zm: sutnist' i perspekty'vy' rozvy'tku u L'vivs'kij oblasti [Mystical tourism: the essence and prospects of development in the Lviv region]. Biznes Inform - Business Inform, 3, 128-137. [in Ukrainian].

18. Misty'chni Karpaty': 10 miscz', opovy'ty'x morokom. [Mystical Carpathians: 10 places shrouded in darkness]. Retrieved from https://hotels24.ua/news/mistichni-karpati-11232096.html. [in Ukrainian].

19. Misty'chni miscya v Ukrayini: 32 lokaciyi, de serce zavmy'raye. [Mystical places in Ukraine: 32 locations where the heart freezes]. Retrieved from https://ua.igotoworld.com/ua/article/1144_misticheskie-mesta-v-ukraine.htm. [in Ukrainian].

20. Misty'chni miscya Ukrayiny'. [Mystical places of Ukraine]. - Retrieved from https://changeua.com/nasha-mistichna-ukrayina/. [in Ukrainian].

21. Misty'chni miscya Ukrayiny', yaki varto vidvidaty'. [Mystical places of Ukraine that are worth visiting]. - Retrieved from https://veterdoit.com/mistychni-mistsia-ukrainy-iaki-varto-vidvidaty-khoch-raz/. [in Ukrainian].

22. Miscya sy'ly' Ukrayiny'. Gy'bli i anomal'ni zony'. [Places of power of Ukraine. Deaths and abnormal areas]. Retrieved from https://freetravel.com.ua/ua/world/ukraine/place-of-power. [in Ukrainian].

23. Moskalenko, Ya. O. «Temny'j» tury'zm yak novy'j vy'd tury'zmu [«Dark» tourism as a new type of tourism]. Retrieved from http://tourlib.net/statti_ukr/moskalenko.htm. [in Ukrainian].

24. Oficijny'j veb-sajt Derzhavnoyi sluzhby' staty'sty'ky' Ukrayiny' [Official website of the State Statistics Service of Ukraine]. www.ukrstat.gov.ua. Retrieved from http://www.ukrstat.gov.ua. [in Ukrainian]. 
25. Oficijny'j veb-sajt Derzhavnogo agentstva Ukrayiny' z upravlinnya zonoyu vidchuzhennya. [Official website of the State Agency of Ukraine for Exclusion Zone Management]. dazv.gov.ua. Retrieved from http://dazv.gov.ua. [in Ukrainian].

26. Pan'kiv, N. M. (2021). TEMNY'J TURY'ZM V UKRAYiNI: FAKTORNY'J ANALIZ TA PERSPEKTY'VY' ROZVY'TKU [DARK TOURISM IN UKRAINE: FACTOR ANALYSIS AND PROSPECTS OF DEVELOPMENT]. Naukovi zapy'sky' SumDPU imeni A. S. Makarenka. Geografichni nauky' - Scientific notes of Sumy State Pedagogical University named after A. S. Makarenko. Geographical sciences, 2 (2). Retrieved from http://repository.sspu.sumy.ua/bitstream/123456789/10943/3/2021_SNSSPU.pdf\#page=149. [in Ukrainian].

27. Sardak, S. E., \& Taran, S. V. (2018). Potencial «temnogo tury'zmu» v krayinax Yevropy' [The potential of «dark tourism» in Europe]. Ekonomika i suspil'stvo - Economy and Society, 18, 27-34. [in Ukrainian].

28. Skeli Dovbusha - pro shho movchat' kam'yani veletni. [Dovbush rocks - what stone giants are silent about]. Retrieved from https://vidviday.ua/blog/skeli-dovbusha/. [in Ukrainian].

29. Smal', I. V. (2013). Tury'zm lyuds'ky'x slabkostej [Tourism of human weaknesses]. Geografiya ta tury'zm - Geography and Tourism, 24, 69-76. [in Ukrainian].

30. TOP-10 misty'chny'x miscz' u L'vovi ta oblasti. [TOP-10 mystical places in Lviv and region]. - Retrieved from https://www.032.ua/news/1845154/top-10-misticnih-misc-u-Ivovi-ta-oblasti. [in Ukrainian].

31. Fuchedzhy', V. I. (2013). SWOT-analiz yak instrument anty'kry'zovogo finansovogo upravlinnya [SWOT-analysis as a tool for crisis financial management]. Aktual'ni problemy' rozvy'tku ekonomiky' regionu - Actual problems of economic development of the region, 9 (2), 156-161. [in Ukrainian].

32. Shy'I'nikova, Z. M., Dul'ceva, I. I., \& Matushkina, M. V. (2018). Tendenciyi rozvy'tku 
«temnogo» tury'zmu ta jogo moty'vacijni aspekty' [Tendencies of development of «dark» tourism and its motivational aspects]. Global'ni ta nacional'ni problemy' ekonomiky' - Global and national problems of economy, 22, 586-591. [in Ukrainian].

33. Dark Tourism - the guide to dark travel destinations around the world. Retrieved from https://dark-tourism.com/index.php. [in English].

34. Seaton, A. V. (1996). Guided by the dark: from thanatopsis to thanatourism. The International Journal of Heritage Studies, 2, 234-244. [in English].

35. Stone, P. A. (2006). Dark tourism spectrum: Towards a typology of death and macabre related tourist sites, attractions and exhibitions. Tourism, 54 (2), 145-160. [in English].

36. Stone, P., Sharpley, R. (2008). Consuming dark tourism: A Thanatological Perspective. Annals of Tourism Research, 574-595. [in English].

37. Foley, M., Lennon, J. (1996). JFK and dark tourism: A fascination with assassination. International Journal of Heritage Studies. Taylor \& Francis, 2(4), 198-211. [in English]. 